\title{
Sciendo
}

Research Article

(C) 2019 Romina Ifeoma Asiyai. This is an open access article licensed under the Creative Commons Attribution-NonCommercial-NoDerivs License (http://creativecommons.org/licenses/by-nc-nd/3.0/).

\section{Deviant Behaviour in Secondary School and its Impact on Students' Learning}

\author{
Romina Ifeoma Asiyai \\ Department of Educational Management and Foundations, \\ Delta State University, Abraka
}

Doi: 10.2478/jesr-2019-0034

\begin{abstract}
Students come to school to acquire knowledge, skills, positive behaviour and values for good citizenship. Students learning become more effective and meaningful when the classroom and school environment is calm and devoid of distractions. This study examined deviant behaviour in schools and how it impacts on students' learning The study drew its sample from a population of public secondary schools in Edo State, Nigeria. The sample comprised 500 teachers selected through random sampling techniques from twenty secondary schools in the state. The questionnaire was the instrument for data collection from the respondents. Descriptive statistics were employed in the analysis of data. The findings revealed that deviant behaviour was prevalent in urban and rural schools but was more prevalent in urban schools than in rural schools. The findings further revealed that the extent of prevalent of deviant behaviour in large schools was more than in small schools. Deviant behaviour severely impacted on students' learning. The study concluded by recommending the adoption of appointing two principals to head large schools. Principals of large schools should employ collaboration with school management team to effectively combat deviant behaviours.
\end{abstract}

Keywords: deviant behaviour, impact, secondary school, students' learning

\section{Introduction}

Education is globally accepted as a powerful tool for inculcating desirable behaviour, positive values, skills and knowledge into learners. Parents send their children to school so that they learn good morals and acquire skills and knowledge needed for them to be able to make maximum contribution to the development of self and their society. While at school, students build relationships with their peers and their teachers. The kind of relationship that exists between students and their teachers can foster their development of strong bonds that enhances their development of good character. The level of connectedness among students and other people they interact with at school can help provide warm support around the students and thus prevent them from indulging in deviant behaviour (Beam, Gil-Rivas, Greenberger \& Chen 2002; Damron-Bell, 2011). Educationists are seriously concerned about producing graduates that are capable of eliciting behaviours that are desirable (Peretomode, 2015).

Deviant behaviour is any behaviour exhibited by members of a group or society which is at variance with established rules of the group or society (Idris, 2016). It has been noted that deviant behaviour increases globally yearly (Hayden, 2007; Damron-Bell, 2011; Hanimoglu, 2019). Deviant behaviour short chains the purpose of education by impacting negatively on teaching and learning in school (Torrente \& Vazsonyi, 2012; Agboola \& Salawa, 2011; Njoroge, Onduso \& Thinguri, 2014; Nabiswa, Misigo, Makhanu, 2016). Without good discipline in school teachers will find it difficult to teach and students cannot learn effectively (DFE, 2010; Hayden, 2011). Deviant behaviour is a 
common feature of secondary schools across the universe. In Britain, Neill (2005) reported that deviant behaviour was high among students as some brought dangerous weapons to school. In another study Hayden (2011) expressed that the number of physical assaults on teachers have escalated and that some students have been bullied by fellow student's thereby causing misery on those students bullied and disrupting learning.

Some students resort to deviant behaviour when they are unable to withstand academic rigours (Babatunde, 2016). The principal ensures proper maintenance of discipline for the smooth functioning of the school and attainment of quality delivery of teaching and learning. A healthy school environment is imperative for students' meaningful learning and quality assurance. As rightly noted by Akomolafe (2012), highly performing schools are committed to desirable student behaviour as well as clear behavioural expectations for all students. The principal is responsible of ensuring that education policies and programmes are efficiently and effectively implemented for the successful attainment of the goals and objectives of the school.

The principal ensures that students are properly controlled by bringing to their knowledge the school rules and regulations and admonishing them regularly to be of good behaviour. Proper control of students' activities is essential to stem down the upsurge of indiscipline among students in the school. Discipline is maintained in school in order to ensure that students learning are not disrupted. The principal in ensuring effective administration of school must ensure that students, teachers and other staff of the school are well checkmated through a vibrant disciplinary policy. In this study, urban schools represent schools in towns or cities having adequate infrastructural facilities. Rural schools are those sited in villages lacking infrastructural facilities. Large schools represent schools having student population above 3,000 while small schools are schools with student population below 3,000.

\subsection{Statement of the Problem}

One of the issues of global concern in effective school administration is handling students' deviant behaviour. Within secondary schools in Nigeria there are several complaints by teachers, parents and the general public of deviant behaviour of students including noise making, inattention, fighting, loitering about, molesting fellow students, threatening and intimidating and waylaying classmates. Deviant behaviours in school can damage the school's reputation both locally and internationally. A school where disruptive behaviour predominates becomes dysfunctional, making it difficult for teaching and learning to go on smoothly. An unsafe school environment is an eye sour to any visitor and an inhibitor of effective learning and teaching.

Management of behaviour problem is a serious challenge in the administration of any secondary toward achievement of goals and objectives. The dynamics of any classroom can change as a result of students' deviant behaviour thus increasing the stress faced by teachers and school administrators. The teacher's ability to effectively manage behaviour problems in the classroom is imperative for goal attainment and improving students learning and academic performance. Though literature abounds on studies which examined deviant behaviour in secondary school, none of the studies covered urban and rural schools and large and small schools in Edo State, Nigeria to the best of knowledge of the researcher. In addition, efforts have not been concentrated on examining the impact of deviant behaviour on students' learning in the state. This observation informed the focus of this study.

\subsection{Specific Objectives of the Study}

This study investigated deviant behaviour in secondary schools. The specific objectives are;

1. To identify deviant behaviours prevalent in urban and rural schools in Edo State.

2. To ascertain the extent of prevalent of deviant behaviours in large and small schools in Edo State

3. To ascertain the impact of deviant behaviour on students' learning. 


\subsection{Research Questions}

Three questions guided this investigation

1. What are the deviant behaviours prevalent in urban and rural secondary schools in Edo State, Nigeria?

2. What are the deviant behaviours prevalent in large and small secondary schools in Edo State, Nigeria?

3. What are the impacts of deviant behaviour on students' learning?

\section{Literature Review}

Deviant behaviour has been described as a behaviour that is at variance with acceptable norms of a school (Peretomode, 2001). It is a negation of school rules and regulations, norms and values of a group or an institution. Any conduct or act that violates the laws or acceptable standards of a society or group is described as deviance. Deviant behaviour is an act or conduct that does not conform with established rules of a society or group (Bolu-steve, 2017; Idris, 2016). What is considered deviant behaviour varies among different societies. Thus a behaviour maybe acceptable by a society but considered deviance by another society. In addition, Igbinovia (1997) maintained that deviance among students could be a way of drawing attention of injustice, and to expose a system's defects so that they can be fine tuned. As expressed by Suleiman (2011), three elements make a behaviour to be described as deviance. These elements are: behaviour that impede an individuals' effective functioning in the society, behaviours that hinders an individual meeting his/her personal needs and behaviour that interferes negatively with the wellbeing of other members of the society. Researchers are concerned about increasing cases of indiscipline among secondary schools. Ali, Dada, Isiaka, \& Salmon. (2014) found that students' misconduct was high in Lagos state secondary schools. Students' poor performance in external examinations was attributed to factors such as lack of facilities, indiscipline and administrative malfeasance among principals (Mbaabu \& Orodho, 2014). Cheng, (2012) attributed deviant behaviour of students to studentteacher relationship and family social economic status. According to Yaman \& Uygumada, (2009), teachers adopt passive learning strategies when the classroom is overcrowded, this breeding ground for deviant behaviour. This situation slows down learning progress (Earthman, 2012).

Discipline in school is the concern of education stakeholders worldwide. In the United States of America $40 \%$ of teachers have left the teaching profession due to disruptive behaviour problems (Mtsweni, 2008). He maintained that many teachers in American schools have sought transfer to schools with less behaviour problems, thus making some schools to be left in the hands of unskilled and novice teachers. Smith and Smith (2016) explained that unruly behaviour of high school students and rampant cases of violence have led to exodus of urban school teachers to rural schools. A single act of unruly behaviour can have a lasting impact on student learning (Mezrigui, 2015). Ali, and Gracey (2013) noted that improved teacher-student relationship is important for building a noise-free classroom learning environment. Therefore principals and teachers have major roles to play in ensuring that a trouble-free school environment is created for improved connectedness, security and safety of student and better learning outcomes.

\section{Methodology}

This qualitative study adopted ex-post facto research design to investigate deviant behaviour prevalent in urban and rural as well as large and small secondary schools and its' impact on students' learning. This design is deemed suitable because the independent variables have already occurred and are not capable of being manipulated under any disguise. The study population comprised all public secondary schools in the state. Through purposive simple random sampling techniques 500 teachers were selected from twenty schools. The questionnaire was the instrument for collection of data from the respondents. It was sub divided into three parts. The first part focused on demographic variables of school location and size. The second part was entitled "Deviant Behaviour Prevalent in Secondary Schools Questionnaire". It contained 12 items meant for urban 
and rural schools as well as large and small schools. The third part of the instrument contained 14 items entitled "Impact of Deviant Behaviour on Students' Learning Questionnaire". The two parts of the questionnaire were structured on a four point scoring scale. The response format for the four point scoring scale is Strongly Agree, (SA), Agree (A), Disagree (D) and Strongly Disagree (SD). The first part of the instrument, percentage scores were used and scores from $75 \%$ and above were rated as High Extent of prevalence of deviant behaviour denoted as (HE) percentage scores within the range of 60 to 74 were rated as Moderate Extent (ME) and percentage scores from 0 to 49 was rated as Low Extent (LE). The third part of the questionnaire, the mean point of the four point scoring scale is 2.50 . This mean score of 2.50 was taken as the bench mark score in making decision whether to accept or not to accept an item. Thus mean scores from 2.50 and above were accepted and given positive sign meaning the item was a deviant behaviour prevalent in school while mean scores from 2.49 down wards were represent with negative sign and hence the item was not deviant behaviour prevalent in school. The instrument was content validated by two Professors in Educational Administration who scrutinized the items and provided comments that were used to modify the final draft. The instrument was tested for reliability through test re-test method. It was administered to 30 teachers who did not partake in the study twice within an interval of two weeks. The scores obtained were divided into two on even and odd basis and computed using Pearson Product Moment reliability coefficient. An index of 0.72 was obtained. In this way, the internal stability of the instrument was ascertained.

\section{Results}

The results of data analysis for answering the research questions are presented in tables below.

Table 1: Deviant Behaviour Prevalent in Urban and Rural Secondary Schools e

\begin{tabular}{lcccccccc}
\hline \multirow{2}{*}{ Items } & \multicolumn{3}{c}{ Urban Schools $\mathrm{N}=280$} & \multicolumn{3}{c}{ Rural Schools $\mathrm{N}=200$} \\
& $\mathrm{FA}$ & $\%$ & $\mathrm{FD}$ & $\%$ & $\mathrm{FA}$ & $\%$ & $\mathrm{FD}$ & $\%$ \\
Fighting & 230 & 82 & 50 & 18 & 150 & 75 & 50 & 25 \\
Lateness to school & 236 & 84 & 44 & 16 & 130 & 65 & 70 & 35 \\
Absenteeism from school & 160 & 57 & 120 & 43 & 180 & 90 & 20 & 10 \\
Bullying & 170 & 61 & 110 & 39 & 100 & 50 & 100 & 50 \\
Examination malpractice & 233 & 83 & 47 & 17 & 186 & 93 & 14 & 7 \\
Smoking cigarette and Indian hemp & 120 & 42 & 160 & 57 & 88 & 44 & 112 & 56 \\
Stealing & 220 & 79 & 60 & 21 & 148 & 74 & 52 & 26 \\
Improper dressing & 218 & 77 & 62 & 22 & 160 & 80 & 40 & 20 \\
Assault & 240 & 86 & 40 & 14 & 128 & 64 & 72 & 36 \\
Noise making & 230 & 82 & 50 & 18 & 168 & 84 & 32 & 16 \\
Violent acts & 200 & 71 & 80 & 29 & 90 & 45 & 110 & 55 \\
Sexual molestation & 170 & 60 & 112 & 40 & 95 & 48 & 105 & 53 \\
\hline
\end{tabular}

The data in Table 1 showed that the deviant behaviour prevalent in urban secondary schools in Edo State are assault $(86 \%)$, lateness to school $(84 \%)$, examination malpractice $(83 \%)$, noise making and fighting $(82 \%)$, stealing (79\%), improper dressing $(77 \%)$, violent acts $(71 \%)$, sexual molestation $(60 \%)$ and absenteeism (57\%). For rural schools, the deviant behaviour prevalent are examination malpractice $(93 \%)$, absenteeism $(90 \%)$, noise making $(84 \%)$, improper dressing $(80 \%)$, stealing $(74 \%)$, lateness to school $(65 \%)$, and fighting

Table 2: Extent of prevalent of deviant behaviour in Large and Small Schools

\begin{tabular}{lcccccccc}
\hline Items & \multicolumn{3}{c}{ Large Schools N $=300$} & \multicolumn{3}{c}{ Small Schools N = 180} \\
& FA & $\% /$ Extent & FD & $\%$ & FA & $\% /$ Extent & FD & $\%$ \\
Fighting & 188 & $63 / \mathrm{ME}$ & 112 & 37 & 86 & $48 / \mathrm{LE}$ & 94 & 52 \\
Lateness to school & 268 & $89 / \mathrm{HE}$ & 32 & 11 & 125 & $69 / \mathrm{ME}$ & 55 & 31 \\
Absenteeism from school & 254 & $85 / \mathrm{HE}$ & 46 & 15 & 110 & $61 / \mathrm{ME}$ & 70 & 39 \\
Bullying & 277 & $92 / \mathrm{HE}$ & 23 & 8 & 128 & $71 / \mathrm{ME}$ & 52 & 29 \\
\hline
\end{tabular}




\begin{tabular}{lcccccccc}
\hline Examination malpractice & 228 & $76 / \mathrm{HE}$ & 12 & 4 & 148 & $82 / \mathrm{HE}$ & 32 & 17 \\
Smoking cigarette and Indian hemp & 146 & $49 / \mathrm{LE}$ & 154 & 51 & 92 & $51 / \mathrm{LE}$ & 88 & 49 \\
Stealing & 174 & $58 / \mathrm{ME}$ & 126 & 42 & 86 & $48 / \mathrm{LE}$ & 94 & 52 \\
Improper dressing & 215 & $72 / \mathrm{ME}$ & 85 & 29 & 108 & $60 / \mathrm{ME}$ & 72 & 40 \\
Assault & 138 & $46 / \mathrm{LE}$ & 62 & 21 & 80 & $44 / \mathrm{LE}$ & 100 & 56 \\
Noise making & 262 & $87 / \mathrm{HE}$ & 38 & 13 & 150 & $83 / \mathrm{HE}$ & 30 & 17 \\
Violent acts & 230 & $77 / \mathrm{HE}$ & 70 & 39 & 120 & $67 / \mathrm{ME}$ & 60 & 33 \\
Sexual molestation & 190 & $63 / \mathrm{ME}$ & 110 & 37 & 78 & $43 / \mathrm{LE}$ & 102 & 57 \\
\hline
\end{tabular}

The data in Table 2 indicates that for large schools, the deviant behaviour prevalent as identified by the respondents are bullying (92\%), lateness to school $(89 \%)$, absenteeism $(88 \%)$, noise making $(87 \%)$, violence acts $(77 \%)$, improper dressing (72\%), fighting and sexual molestation $(63 \%)$. the extent of prevalent of deviant behaviour in large schools is high. But for small schools, the deviant behaviour prevalent are noise making (83\%), examination malpractice (82\%), bullying (71\%), violent acts (^ $67 \%)$ and improper dressing (60\%). Deviant behaviour is prevalent to a moderate extent in small schools.

Table 4: Mean and standard deviation scores showing ways deviant behaviour impact on students' learning

\begin{tabular}{|c|c|c|c|}
\hline Items on impact of deviant behaviour on students learning & Mean & $\begin{array}{l}\text { Std } \\
\text { Dev }\end{array}$ & Remark \\
\hline $\begin{array}{l}\text { Noise making during lesson in the classroom distracts students from } \\
\text { learning topics taught }\end{array}$ & 3.42 & 0.543 & + \\
\hline $\begin{array}{l}\text { Noise making can attract flogging of students by the teacher thereby } \\
\text { inflicting injury on their body }\end{array}$ & 3.00 & 0.640 & + \\
\hline $\begin{array}{l}\text { Students can lose full concentration of topics taught due to deviant } \\
\text { behaviour }\end{array}$ & 2.98 & 0.772 & + \\
\hline $\begin{array}{l}\text { Students who indulge in deviant behaviour may not be able to realize their } \\
\text { academic potentials }\end{array}$ & 2.70 & 0.903 & + \\
\hline $\begin{array}{l}\text { Deviant behaviour in form of lateness to school can make students to be } \\
\text { given punishments which make them to miss first lesson of the day }\end{array}$ & 3.33 & 0.811 & + \\
\hline $\begin{array}{l}\text { Students loss the time meant for learning serving punishment due to } \\
\text { deviant behaviour }\end{array}$ & 3.40 & 0.672 & + \\
\hline $\begin{array}{l}\text { Deviant behaviour sometimes makes teachers to use negative labels on } \\
\text { students thereby making them dislike school }\end{array}$ & 2.80 & 0.553 & + \\
\hline $\begin{array}{l}\text { The punitive measures used to correct deviant behaviour can hamper a } \\
\text { students' self concept }\end{array}$ & 3.50 & 0.491 & + \\
\hline $\begin{array}{l}\text { Teachers use of corporal punishment for deviant behaviour can make } \\
\text { students to drop out from school }\end{array}$ & 2,90 & 1.00 & + \\
\hline $\begin{array}{l}\text { Students can develop loss of interest in learning due to punitive measure } \\
\text { used to control deviant behaviour }\end{array}$ & 3.25 & 0.482 & + \\
\hline $\begin{array}{l}\text { Teacher stereotyping on individual student who indulge in deviant } \\
\text { behaviour can damage him emotionally }\end{array}$ & 2.78 & 0.662 & + \\
\hline Students who perpetrate deviant behaviour may record academic failure & 2.76 & 0.680 & + \\
\hline $\begin{array}{l}\text { Continued absenteeism can make a student not to perform well } \\
\text { academically and thus drop out from school }\end{array}$ & 2.96 & 0.60 & + \\
\hline $\begin{array}{l}\text { Serious case of deviant behaviour can make a student to be suspended } \\
\text { or expelled from school }\end{array}$ & 3.20 & 0.82 & + \\
\hline Grand Mean & 3.06 & & \\
\hline
\end{tabular}

The result in Table 3 indicates that the mean score for each of the items exceeded the cut-off mean score of 2.50. Therefore all the fourteen items represent the impact of deviant behaviour on students' learning. The grand mean score of 3.06 is high. The implication of this is that deviant behaviour impacted seriously on students' learning. 


\section{Discussion}

\subsection{Extent of prevalent of deviant behaviour in urban and rural secondary schools}

The findings of the study revealed that the extent of prevalence of deviant behaviour in urban secondary schools are assault, lateness to school, examination malpractice, noise making, fighting, stealing improper dressing ,, violent acts, sexual molestation and absenteeism. The extent of prevalence of deviant behaviour in rural schools are examination malpractice, absenteeism, noise making, improper dressing, stealing lateness to school and fighting. Examination malpractice and nose making in the classroom were the most prevalent forms of deviant behaviour revealed by this study in urban and rural schools. This finding is similar to that of Amini-Philips \& Chukwuma (2017) and Whawo (2015) that examination malpractice stealing and not obeying class rules was common among students. In addition, Chikwature, Oyedele and Ganyani (2016) found that bullying, noise making and stealing were disruptive behaviours among students in Mutare districts.

\subsection{Extent of prevalent of deviant behaviour in large and small secondary schools}

This study revealed the extent of deviant behaviour in large and small schools. For large schools, deviant behaviours like bullying, lateness to school, absenteeism, noise making and violence acts were prevalent to a high extent. Improper dressing, fighting and sexual molestation were prevalent to a moderate extent. Deviant behaviour appears to be more prevalent in large schools than I small schools. The reason for this could be attributed to the fact that most large school classrooms are overpopulated. Teachers of such classrooms spend most of the time trying to control students deviant behaviours. For small schools, the findings of this study revealed that noise making and examination malpractice were prevalent to a high extent. Bullying,, violent acts and improper dressing were moderately prevalent in schools.

\subsection{Impact of deviant behaviour on students learning}

The findings of this study showed that deviant behaviour like noise making impacts negatively of students' learning by making inattentive and to lose concentration on topics taught. Noise making can also attract flogging by the teacher which can result to injury on student's body. Students who come late to school are often subjected to punishment which makes them to miss the first lesson of the day. In some cases, the student can miss the first and second lessons which are usually mathematics and English. Students therefore lose the instructional time and knowledge of key subjects. Such students may find it difficult to cope academically in the subjects. The punitive measures used by teachers and school authority to control deviant behaviour could cause severe impacts on the students. The use of negative labels on students because of their indulgence in deviant behaviours can make them to dislike school, develop low self concept and drop out of school.. The findings of this study lends credence with Chikwature, Oyedele and Ganyani (2016) that students find it difficult to concentrate and fully absorb topics taught in a classroom dotted with deviant behaviours. Similarly, the finding has the support of Morris (2005) that deviant behaviour frustrates teachers and students efforts at teaching and learning thereby hindering the attainment of the goals of education. Agreeing with the findings of this study, Appelbaum, Laconi and Matousek (2007) averred that deviant behaviour whether minor or major, overt or covert, impedes students learning and limits the school in achieving the goals and objectives. Additionally, the findings agreed with Bhagavi and Caeiro (2017). They maintained that deviant behaviour impacted negatively on students, leading to failure and drop out from school.

\section{Conclusion}

From the findings of this study, it can be concluded that deviant behaviour is prevalent in urban and rural secondary schools in public secondary schools in Edo State, Nigeria. It can also be concluded that the extent of deviant behaviour in large schools is high and moderate in small school. Another 
conclusion that can be drawn from the findings of the study is that deviant behaviour have impacted severely on students learning.

\section{Recommendations}

Based on the findings, the following are recommended:

1. Principals and teachers should device appropriate punitive measures in controlling deviant behaviour in school.

2. Principals should use parents teachers association to sensitize parents and guardians of the need to ensure that that children come early to school and do not absent themselves from school.

3. Principals should ensure that they regularly admonish students during morning assembly on good conduct.

4. The school authority should occasionally invite moral transformation agents to school to give talks to students on good moral behaviour.

\section{References}

Agboola, A. A \& Salawa, R. O. (2011). Managing deviant behaviour and resistance to change. International Journal of Business and Management, 6(1), 235-242.

Akomolafe, C. O. (2012). A comparative study of principals administrative effectiveness in public and private secondary schools in Ekiti State, Nigeria. Journal of Education and Practice, 3(13), 39-45.

Ali, A. A., Dada, i. t., Isiaka, G. A.., \& Salmon, S. A. (2014). Types, causes and management of in disciplinary acts among secondary school students in Shomolu local government area of Lagos State. Journal of Studies in Social Science, 8(2), 254-287.

Ali, K. and Gracey, D. (2013). Dealing with students disruptive behaviour in the classroom: A case example of the coordination between faculty and assistant dean for academics. The Journal of Informing Science and Information Technology, 10, 1-15.

Amini-Philips, C., \& Chukwuma, O. C. (2017). Corruption and administration of higher education institutions in Nigeria. World Journal of Social Science, 4(2), 12-22. https://doi.org/10.5430/wjssv4n2p12.

Appelbaum,S. H, Laconi, G. D. and Matousek, A. (2007). Positive and negative deviant workplace behaviours: Causes, impacts and solutions. Corporate Governance, $7(5), 586-598$.

Babatunde, A. N. (2016). Influence of reinforcement technique in reducing students' classroom undesirable behaviour as expressed by secondary school teachers in Ilorin metropolis, Kwara State. Unpublished M.Ed Dissertation, University of Ilorin.

Bhagavi, J., and Caeiro, D. (2017). Teachers perception about students indulging in deviant behaviour. The International Journal of Indian Psychology, 4(2), 93.

Beam, M. R., Gil-Rivas, V., Greenberger, E. \& Chen C.(2002). Adolescent problem behaviour and depressed mood: risk and protection within and across social context. Journal of Youth and Adolescence, 31, 343357.

Bolu-steve, F. N. \& Esere, M. O. (2017). Strategies for managing deviant behaviour among in-school adolescents as expressed by secondary school counselors in Kwara State, Nigeria. Inkanyiso Journal of Humanities and Social Sciences, 9(1), 87-98.

Chikwature, W., Oyedele, V. \& Ganyani, L. (2016). Effectsof deviant behaviour on academic performance in Mutare urban primary schools in Mutere District. European Journal of Psychological Research, 3(1), 3545. Source: www.idupublications.org.

Cheng, J. (2012). The effect factor for students' deviant behaviour. The Journal of Human Resource and Adult Learning, 8(2), 26-32.

Damron-Bell, J. (2011). The development of deviant behaviour in adolescents: The influence of students characteristics and school climate. Doctoral Thesis, University of Louisville, Louisville, Kentucky.

Earthman, G. I. (2012). School facility condition and student achievement. UCLA's Institute for democracy, education and access, Virginia.

Hayden, C. (2011). Crime, anti-social behaviour and schools in Britain- are all schools at risk? Inaugural Lecture Series, University of Portsmouth.

Hanimoglu, E. (2018). Deviant behaviour in school setting. Journal of Education and Training Studies, 6(10),

Idris, O. (2016). Causes of deviant behaviour among in-school adolescents in Lagos. Unpublished M. Ed Dissertation University of Lagos, Akoka. 
Igbinovia, P. E. (1997). Students deviance in Nigerian tertiary institutions: An observation. International Journal of Adolescence and Youth, 7(1), 83-92. DOI:10.1080/026738431997.9747812.

Mbaabu, L. N. \& Orodho, J. A. (2014). Primary school management: Focus on constraints faced by head teachers in managing primary schools in Chogoria Division, Meru County, Kenya. Journal of Developing Countries Studies, 4(20), 159-167.

Mezrigui, Y. (2015). How teachers can meet the challenges of sizeable classes and student disruptive behaviour. Journal of Educational and Social Research, 5(2), 107-117. Doi

;10.5901/jesr.2015v5n2107.

Morris, E. W. (2005). "Tuck in the Shirt" race, class, gender and discipline in urban school. Sociological Perspectives, 48(!), 25-48. Doi:10.1525/sop.2005.481.25

Mtsweni, J. (2008). The role of educators in the management of school discipline in the Mkangala region of Mpumalanga. M. Ed Dissertation, University of South Africa.

Nabiswa, J. Misigo, B. L., Makhanu, F. N. (2016). Analysis of students deviant behaviour most prevalent in schools in Bungoma County. Journal of Research in Humanities and Social Sciences, 4(11), 19-23. www.questjournals.org.

Njoroge, E. W. Onduso, T. M. \& Thinguri, R. (2014). School leadership role in predicting deviant behaviour among secondary school students in Gatanga District, Muranga County. Research Journal of Education, 9, 1-15.

Neill, S. R. (2005). Knives and other weapons in London schools. The International Journal of School Disaffection, 3(2), 27-32.

Peretomode, V.F. (2001). Educational administration applied concepts and theoretical perspectives for students and practitioners. Lagos: Joja Educational Research and Publishers Ltd.

Peretomode, V. F. (2015). Emergent issues and educational development in the century. Paper delivered during as Welcome address at the Faculty of Education Delta State University, Abraka International Conference..

Smith, D. L. \& Smith, B. J. (2006). Perceptions of violence: The views of teachers who left urban schools. The High School Journal, 89 34-42.

Suleiman, J. M. (2011). Causes and remedies of deviant bahaviour among adolescents as expressed by teachers in Kwara State. Unpublished M. Ed Dissertation, University of Ilorin, Ilorin.

Torrente, G. \& Vazsonyi, A. T. ( 2016). Adolescence and social deviance. Anales de Psicologia, 28(3), 639-642.

Whawo, D. D. (2015). Identifiable corrupt practices among staff and students of secondary schools in Delta State of Nigeria. International Journal of Secondary Education, 3(5), 50-54. DOI:10.11648/J.ijsedu.20150305.12

Yaman, H., \& Uygulamada, K. (2009). Teachers' views on the applicability of the Turkish course curriculum in crowded primary classrooms, Egitm Bilimleri, 9(1), 349-359. Retrieved from: https://www. http://w3.gazi.edu.tr/ mozbay/atiflar.htm. 